\title{
Qualities before Quantities: A Framework to Develop Dynamic Assessment of the Nonprofit Sector
}

\author{
${ }^{1}$ Leadership and Interdisciplinary Studies, Arizona State University, Tempe, AZ, USA, E-mail: eac@asu.edu
}

\begin{abstract}
:
Metrics are essential for assessing performance and guiding course corrections. However, selecting the wrong metrics can damage organizations and communities by promoting resource investment in activities that don't lead to envisioned impacts. Therefore, it is essential to reflect on what qualities an effective set of metrics should possess before insisting on quantification. This concept paper articulates design principles for developing an index of the nonprofit sector. Drawing from complexity theory and axiology (philosophy of values), the paper explains fundamental questions and values considerations to assist index developers in creating effective measures. It argues for the use of a capabilities approach, operationalized as multiple capitals, as the design architecture. It suggests the social accounting framework of Integrated Reporting as a way to track these capitals over multiple levels and time horizons.
\end{abstract}

Keywords: capabilities, multiple capitals, integrated reporting, nonprofit policy

DOI: $10.1515 /$ npf-2018-0009

Is the United States' nonprofit sector healthy or decaying? How can we assess changes in its vitality from year to year? Metrics are essential to answer such questions. They make performance monitoring and course correction possible. They also enable benchmarking that guides effective policymaking.

This conceptual paper argues for a capabilities approach (Nussbaum 2001; Sen 2005) as the foundation for a nonprofit sector index. It presents values considerations and design principles from complexity theory as its rationale, operationalizing capabilities as multiple capitals (e. g. financial, social, political, natural). The framework of Integrated Reporting (a type of social accounting) is introduced as a way to align multiple levels of analysis (individual, organizational, community, nation). Examples illustrate how this approach can accommodate context dependence, synergies, and tradeoffs to guide policymaking. The goal of this paper is to foster a collective discussion about a universal measurement architecture that can accommodate the many complexities of the nonprofit sector.

\section{Why Does the Nonprofit Sector Need an Index?}

An index is an aggregation of metrics that assess quantitatively a state or phenomenon that cannot be measured directly. For example, the Legatum Prosperity Index assesses global prosperity by compiling national indicators such as economic quality, business environment, governance, personal freedom, social capital, safety and security, education, health, and natural environment. These data then inform policy development (The Legatum Institute 2017).

The purpose of an index is threefold. First, it portrays the current state of a phenomenon. Second, it illuminates cycles and trends over time, making it possible to assess its likely future direction. Third, it guides effective policymaking (Stock and Watson 1989). The process of index development includes selecting what is to be measured and identifying the correct blend of leading (predictive), lagging (confirmatory), and coincidental (real-time) measures. Other process components include determining the methodology for collecting and interpreting the data, and comparing those with data from prior years to assess trends and predict future trajectories (Stock and Watson 1989).

While the private and public sectors assess their health with measures such as financial statements, the Dow Jones Average, and Gross Domestic Product, the nonprofit sector currently has no definitive index to measure its vitality. This is problematic because without a commonly accepted measurement framework trackable over time, it is difficult to recognize trends and develop effective policy interventions. Lack of sector-wide data also 
makes it challenging to focus collective attention, organize coordinated action, and secure resources to address systemic problems.

Yet measures exist at the macro (societal) and organizational levels that can be used to develop such an index. Examples at the macro level include community wellbeing indicators (e. g. Warner and Kern 2013; Kim 2016) that aggregate measures such as health outcomes, social cohesion, land and water quality, and economic opportunity. Healthy Communities initiatives (Norris 2014) and the National Conference on Citizenship's Civic Health Index (National Conference on Citizenship 2017) measure civic health, such as the Greater Seattle Civic Health Index (Seattle CityClub 2018) and Texas Civic Health Index (Jennings and Bhandari 2018). Similarly, universities in San Diego (Deitrick et al. 2016), North Central Florida (Jones et al. 2016), and elsewhere have researched and issued reports on the vitality of their communities' nonprofit sectors.

Regional initiatives like these provide useful information for local policymaking and action. However, their different methodologies and data categories make national and global comparison very difficult. Further, these measures are not necessarily applicable at the organizational level. If they were, nonprofit organizations could use these same metrics to develop programmatic goals and assess organizational impact and effectiveness to populate community indicators.

Instead, nonprofit organizations " ... find themselves devoting scarce resources to juggling multiple, and sometimes irreconcilable, performance and accountability expectations" (Ebrahim 2010, 629). It not surprising, then, that focus regularly defaults to financial measures since financial sustainability is problematic for many organizations. Examples of common financial metrics include solvency (e. g. financial ratios) and liquidity (e. g. cash flow, short-term investments and debt), with more progressive organizations adding measures of financial flexibility such as reputation, creditworthiness, and donor engagement (Zietlow 2010). However, financial metrics overlook non-market measures of well-being, such as health and social cohesion

\section{Problems of Measurement}

Many widely accepted metrics have been developed for the private sector. Why, then, is measurement more difficult in the nonprofit sector? Here I discuss four reasons: intangible resources, interdependencies across time and scale, the need for collaboration among people with divergent viewpoints, and path dependence.

\subsection{Intangible Resources}

Much of the nonprofit sector's value creation is achieved through intangible inputs, outputs, outcomes, and impact. Non-physical outcomes and impact include wellbeing, health, cultural vitality, and advocacy (Scott 2011). For example, a study of the Australian Red Cross Blood Service found that intangibles such as donor and volunteer relationships, product safety, and public confidence in the organization were some of its most important value propositions (Fletcher et al. 2003). Similarly, many resource inputs are intangible and therefore difficult to measure (Allee 2000; Niven 2011; Lev 2005). Examples include social capital, e. g. relationships and trust (Fukuyama 2001), knowledge and intellectual capital (Kong and Prior 2008), and brand and reputational capital (Seitanidi 2007).

\subsection{Interdependencies}

Measurement is also problematic because value creation involves multiple time horizons and units of analysis. These can be difficult to isolate and identify, let alone quantify. The process of value creation spans multiple analytical level (e.g. individual, organization, network, community). It also relies on synergistic interactions over short-term and long-term time horizons (Emery and Flora 2006). Nonprofit resources are not transformed through a simple input-mediator-output model of causation. Rather, value creation occurs through a process of bidirectional causation (e.g. mutual influence) and recursion (feedback loops, where an output becomes a new input for the system, sometimes at a different level). Such resource interdependencies entail coupling (essential linkages between two or more resources). This co-action of elements can produce emergence, the development of a qualitatively different macro phenomenon arising from micro-level interactions (Baum and Singh 1994; Morris 2000; Maruyama 1978). The sector's traditional planning and reporting tools (e. g. logic models, financial statements) do not capture these complex dynamics. This can lead to decoupling that suppresses emergence. 


\subsection{Complex Challenges and Contested Frames}

Third, and perhaps most challenging, is that the nonprofit sector typically deals with messy problems that do not have clear solutions (Ackoff 1979). These complex problems require ongoing coordination and locally derived knowledge to co-create effective solutions (Brown et al. 2012; Rittel and Webber 1973). However, effective problem solving requires a common understanding of the problem. Complex problems often produce different problem framings, resulting in conflicted approaches to solving them (Weber and Khademian 2008).

Metrics seek to reduce uncertainty in complex situations (Head and Alford 2015). Yet poorly designed metrics can inadvertently isolate parts of the system through reductionist analysis (Fairholm and Card 2009). Metrics also privilege quantitative information, particularly financial (Gray 2006). This promotes underinvestment in intangible resources essential to long-term value creation (De Soto 2000). Ongoing underinvestment creates a nonprofit starvation cycle that can lead to organizational decline over time (Lecy and Searing 2015; Wing and Hager 2004).

\subsection{Path Dependence}

Failure to invest adequately in capacity and infrastructure today can limit future options through path dependency (Todorova and Durisin 2007; Schmidt 2010; Cohen and Levinthal 1990). Metrics can also divert from purpose, becoming drivers of an organization rather than one of its wheels (King 2017). Finally, metrics can be used - either purposefully or inadvertently - as a disciplinary technology to exert control over others, limit their agency, and preserve power imbalances (Doolin 1998; Foucault 1984).

The stakes are high for developing a nonprofit sector index. Lack of holistic measures promotes piecemeal solutions, where parts of a major social challenge are addressed but do not solve the problem. For example, social service organizations work to feed, house, and clothe people without homes. But without related progress on policy issues such as mental health funding, minimum wage levels, and housing prices, the underlying causes of homelessness remain. What is needed is an understanding of how these various pieces interact across micro, meso, and macro levels so that effective policies and programmatic interventions can be developed holistically (Toro and Warren 1999).

\section{Design Questions and Guiding Principles}

An index can help develop this interdependent, multi-level understanding. Selecting the wrong metrics, however, can damage organizations and communities by promoting resource investment in activities that do not lead to envisioned impacts and leave clients without services (Cutter et al. 2008). Before choosing measures, it is vital to reflect on the purpose and goals of the measurement, working with stakeholders to identify desired qualitative attributes before diving into quantification (Meadows 1998). This deliberation should consider tradeoffs that choices entail, because selecting what and how to measure signals what we value and simultaneously constitutes and perpetuates values (Meadows 1998; Bowles 1991; Graeber 2001).

To develop an index framework that addresses the measurement issues identified above, this paper asks two fundamental questions: 1) how can a nonprofit health index reflect the full span of the nonprofit sector's value creation performance, and 2) how can interaction effects be measured and accounted for across levels? Complexity science and axiology (philosophy of values) serve as the conceptual pillars of a proposed framework. A complexity approach is essential because human systems are unpredictable and interdependent, e. g. small perturbations can have effects elsewhere in the system that cause serious unintended consequences (Carlson and Doyle 2002). Metrics seek to impose control and order on a system, but control is not always possible in complex environments (Cameron and Abouchar 1991).

Thus, rather than seeking to reduce complexity, metrics and analytical methods must allow for selforganization and emergence. Emergent phenomena arise spontaneously from the interactions of individual agents (Rickles, Hawe, and Shiell 2007). Enhancing agency fosters emergence and increases the generative potential of a system (Bandura 2006). Because human systems are driven and affected by agentic choices and purposive goal setting (teleology) it is imperative to articulate the values that underlie choices and goal selection. Index development must provide a way to make explicit what people value (e. g. freedom, inclusion, equity), identify what they want to strive for (e. g. mission, goals, objectives), acknowledge and consider tradeoffs, and account for consequences of their choices and their impact on others (Mayer, van Daalen, and Bots 2013). 


\title{
4 Capabilities as a Design Framework
}

An index based on a capabilities approach is a way to operationalize these conceptual pillars. The premise of capabilities is that the development of individual capacities in people leads to development (emergence) of organizational and civic capacity (Sen 2005; Nussbaum 2001). A capabilities approach starts with the question, "What is each person able to do and to be?" (Nussbaum 2011, 18), with the goal of increasing personal freedom and agency.

A capabilities approach aligns with three elements of resilient complex systems: diversity, reciprocity, and emergence. Diversity is heterogeneity characterized by noticeable variation of social and cultural identities among people co-existing in the various contexts (Stevens Institute for Technology 2006). More diversity increases a system's stability and capacity to generate new options (Folke 2006; MaCann 2000). Reciprocity (mutual exchange of beneficial acts) promotes trust, sustained exchange, and ongoing alignment toward shared goals under dynamic conditions (Bruni 2008). This exchange process is recursive: the outputs of the system (trust, shared goals and values) loop back through a feedback process to become new physical and social inputs for subsequent cycles (Tidball \& Weinstein 2011). Together, the qualities of reciprocity and diversity promote a system's capacity for emergence, fostering its resilience (the sustained ability to recover from perturbations). These qualities enhance the system's evolvability, the capacity to expand degrees of freedom by leveraging randomness. This improves the system's ability to fit with a greater number of possible future environments (Nature 2018).

From a values perspective, a capabilities approach supports freedom, dignity, and the emergence of community flourishing because it promotes continuous expansion of individual and collective degrees of freedom (Nussbaum 2011). Capabilities exist and can be measured at the organizational and societal level (Kato, Ashley, and Weaver 2017), providing an architecture that accommodates emergence through mutual interaction effects among people, organizations, networks, and communities. In organizations, capabilities are often discussed in terms of value creation capacity, particularly absorptive (Todorova and Durisin 2007), adaptive (March 1991), and generative (Castillo and Trinh Forthcoming). These activities are generally called capacity building in the nonprofit sector (Castillo 2016; Fowler 2004).

\section{Social Accounting as a Way to Measure Capabilities}

\author{
It is tempting, if the only tool you have is a hammer, to treat everything as if it were a nail.
}

Maslow 1966

If the purpose of accounting is to provide information about relevant events, communicate about and promote control of organizational assets, and produce data to support decision making (Sorter 1969; Gray 2006), then financial accounting neglects essential aspects of the nonprofit sector's value creation inputs and outputs (e. g. moral purpose, cooperation, mutual benefit). Accountability—the process of being held responsible for one's choices and actions - is another important objective of accounting. However, accountability consists of vertical (legalistic) and horizontal (relational) dimensions (Moncrieffe 2011). Relational elements include equitable representation of interests, transparency, and participative deliberation. Because conventional accounting focuses solely on financial resources, it addresses only the vertical aspect of accountability (demonstrating legal compliance). It does not attend to relational accountability. A nonprofit index must therefore address both vertical and horizontal accountability to reflect its relational and moral dimensions (Vosselman 2016).

How can capabilities (e. g. agency, value creation potential) address these gaps? And how can they be measured and accounted for to provide a starting point for an index? Social accounting emerged in the 1970s as a way to attend to values and relational accountability, recognizing both social and economic dimensions and impacts of organizations. Social accounting illuminates the value that an organization adds to its stakeholders through its production of outputs, outcomes, and externalities (Land 1996). Social accounting represents both financial and non-financial resources, sometimes ascribing financial values to non-monetized outcomes such as volunteer labor through market comparisons (Mook, Richmond, and Quarter 2003). Social entrepreneurs use various forms of social accounting to show how they produce social return on investment (Nicholls 2009). In a nonprofit context, this value added approach conveys that wealth is produced as a result of many different agents working together cooperatively for public benefit (Burchell, Clubb, and Hopwood 1985; Mook 2014).

Social accounting provides a fuller picture of an organization's resource inputs and outputs and the effect these have on various stakeholders, e. g. customers, vendors, shareholders, employees, communities where they do business, etc. (Mook and Machokoto 2017). One challenge, however, is comparability. In conventional financial accounting, Generally Accepted Accounting Principles (GAAP) make comparing balance sheets of 
various organizations rather straightforward. The non-standardized aspect of social accounting makes comparison more difficult.

\subsection{Integrated Reporting}

To solve this problem, frameworks have been developed to systematize the reporting of non-GAAP information. Integrated Reporting (IR) is one such model. It uses multiple capitals to portray a firm's past performance, current state, and future value creation capacity. A capitals approach accomplishes this because capital by definition (enduring resources that can produce more resources) entails future productive capacity, akin to capabilities (Sen 2005; Nussbaum 2001). Integrated Reporting assesses and communicates, "how an organization's strategy, governance, performance, and prospects - in the context of its external environment-lead to value creation in the short, medium and long term" (International Integrated Reporting Council 2016, 6). It uses both qualitative descriptions and quantitative measures to depict the process by which an entity transforms multiple forms of capital (tangible and intangible) into value.

Resource inputs in the IR model include financial, manufactured, intellectual, human, social, and natural capital. However, sociologists would argue it fails to account for structural relations and symbolic capital (Bourdieu 1989). These components of value creation include cultural capital (Bourdieu 1993), rule of law (De Soto 2000), spatial proximity (Goodchild and Janelle 2010; Rutten, Westlund, and Boekema 2010), and processes (Galbraith 1995, 2011). The IR model also portrays how some of these outputs, outcomes, and impact cycle back to become new inputs.

\section{Developing an Index}

Operationalizing capabilities as multiple forms of capital (e. g. social, intellectual, political, reputational) is a way to account for both tangible and intangible resources and value creation. A starting point for creating a national index is to gather existing indicators and sort them into a capitals framework. Organizations such as Independent Sector, GuideStar, National Council on Nonprofits, National Center for Charitable Statistics, Urban Institute, Nonprofit Finance Fund and others conduct ongoing research and share their findings regularly. Much of these data can be categorized as capitals. Building from those and other reports, Table 1 provides examples of possible indicators for each type of capital at the individual, organizational, community, and national levels. 


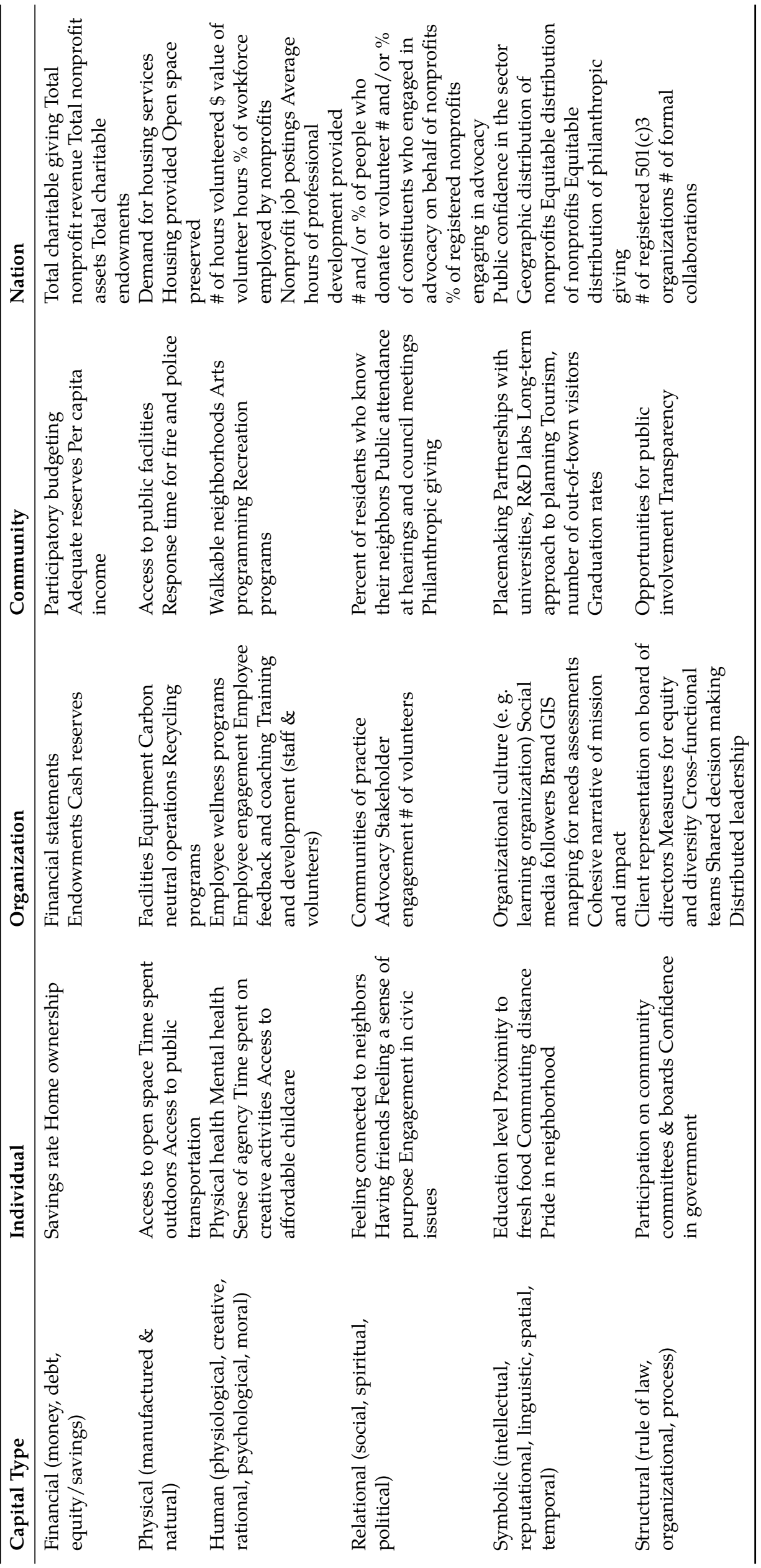


At the community level, regional wellbeing indicator initiatives can be operationalized as multiple capitals (Kee 2017). Similarly, Anand, Hunter, Carter, Dowding, Guala, and Van Hees (2009) describe a variety of measures for capabilities at the individual level. Kato, Ashley, and Weaver (2017) have identified measures used at the organizational and community levels. It would be fairly straightforward to translate these various capabilities measures at each level into a multiple capitals framework.

At the organizational level, adopting a capabilities approach is a way for organizations to align their operations, capacity building, program evaluation, strategic planning, and stakeholder reporting. To begin, nonprofits can create measures for each type of capital in a way that is meaningful to them. For example, tracking the number of people who follow the organization on social media could be an indicator of its social capital. This connects a strategic objective (increasing community engagement) to a key performance indicator (Kanter and Paine 2012) that could be used in an organization's annual reporting as an indicator of its social capital.

Scholars have developed a variety of measurement methods, including surveys and network analysis (Lakon, Godette, and Hipp 2008), for many of the capitals. Measures exist for social capital (Van Der Gaag and Webber 2008), intellectual capital (Petty and Guthrie 2000; Chen, Zhu, and Xie 2004; Liebowitz and Suen 2000), reputational capital (Wartick 2002; Cravens, Goad Oliver, and Ramamoorti 2003), political capital (Casey 2008), rule of law (Skaaning 2010; Santos 2012); and spatial capital (Marcus 2010). Adopting such measures and framing nonprofits' work as capabilities development (i. e. multiple capitals) would provide a strong narrative to explain their value creation process and impact. It also provides powerful new language grounded in sound logic (complexity theory) to discuss their work with policymakers, donors, volunteers, and other stakeholders.

At the individual level, measures can assess capabilities developed among people served by the organization. For example, surveys can assess to what extent program participants increased their connections to other people in the community (social capital), knowledge and skills (intellectual capital), and voting and civic participation (political capital). With thoughtful design, these measures could serve as an evaluation framework to assess program effectiveness (e. g. administering pre- and post-program surveys). Instead of an organization being pulled to attend to multiple accountabilities, framing program objectives as the development of capabilities (multiple capitals) aligns evaluation with the organization's social accounting reporting. In a similar vein, annual evaluations and professional development plans for employees can be translated into a multiple capitals framework (e. g. increasing their skills and knowledge; improving workplace relationships; increasing their level of engagement). Aggregating this data provides an assessment of the organization's human capital for its social accounting reporting.

\subsection{A Case Example}

To illustrate what this might look like in practice, let us consider the community transformation described in Emery and Flora's 2006 research on rural development and how this could be depicted using Integrated Reporting. That case study begins by describing how community leaders used their social capital to recruit participants for an eight-month leadership development program. Using human, financial, and intellectual capital to offer the course, it trained three cohorts of people. Besides increasing students' knowledge and leadership skills, the evaluation found development of cultural capital (changing norms that increasingly valued community involvement) and political capital as "... people outside the traditional leadership structure were finding voice in community affairs."

This in turn affected structural aspects of power as more youth and diverse stakeholders became involved. For example, the community's 2004 election saw multiple candidates run for each position, whereas before it had been difficult to recruit even one person to run. "Without changes in traditional leadership structure and actors, the community could not have mobilized citizens to support changes" (Emery and Flora 2006, 25). It also attracted new investment of financial capital from utility companies and growth in planned giving bequests through the program's partnership with the Nebraska Community Foundation. In the business community, the program's local entrepreneurship team worked with youth, businesses, and the regional economic development council to grow its entrepreneurship portfolio to over 100 businesses and attract new manufacturing infrastructure. Figure 1 portrays some of the value creation transformations using an Integrated Reporting diagram. 


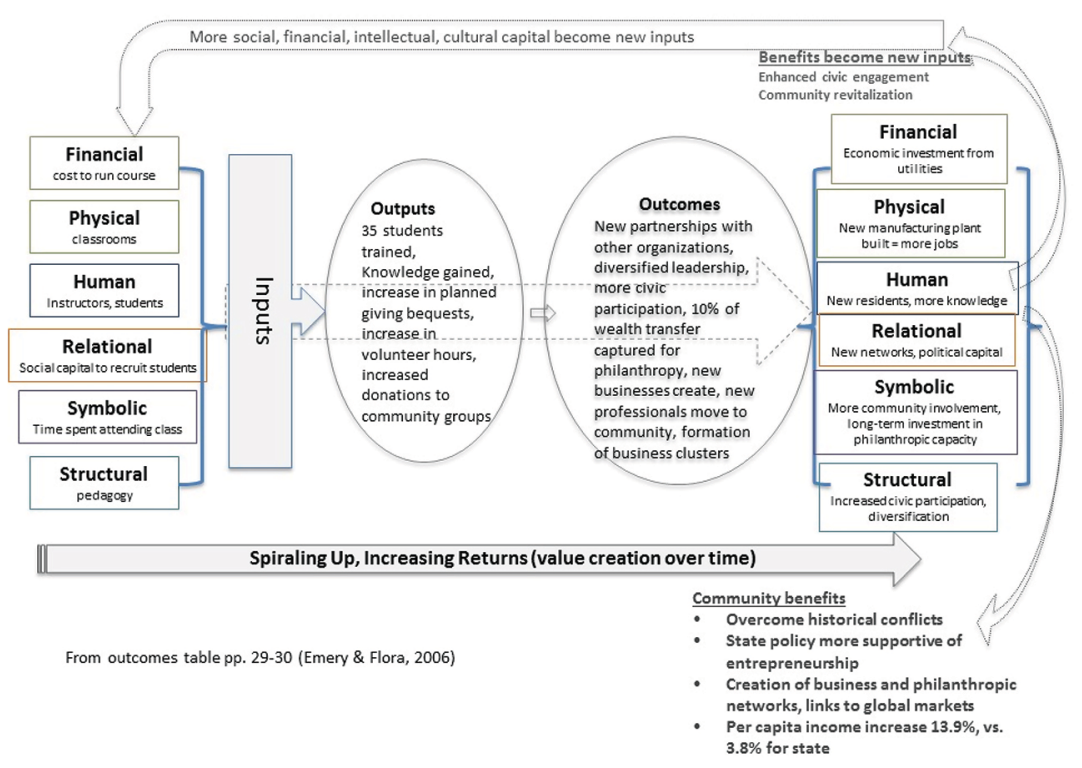

Figure 1: An integrated report for Emery \& Flora's Spiraling Up Emery and Flora (2006).

Some readers may notice this diagram resembles a logic model, a tool used in the nonprofit sector to plan and evaluate programs and illustrate a theory of change. This is one of the major benefits of Integrated Reportingit promotes integrated thinking (the alignment of strategy, resource inputs, and value creation processes to show how these combine to produce outputs, outcomes, and impact) in a way that links strategy to reporting.

Another benefit is that IR captures externalities (impacts the organization makes on the external environment). Nonprofits' externalities are generally positive, e. g. the public benefit they create through mission fulfillment. The IR model makes this public goods production very visible. Similarly, negative externalities such as pollution (if applicable) should also be portrayed to demonstrate transparency and accountability (Muller, Mendelsohn, and Nordhaus 2011). Adopting Integrated Reporting in the nonprofit sector is thus a way to normalize transparent reporting of a firm's impacts on society. This can raise public expectations for similar transparency in the private sector.

Why is it desirable to adopt a multiple capitals approach to metrics across multiple levels? First, as discussed previously, value creation happens through interactions across multiple levels and through indirect effects (Kenny 2018). Outputs at one level become new inputs at other levels. Understanding the health of each level avoids reductionism. Second, the sector in many ways has become siloed by sub-sectors (e. g. environmental, human services, arts and culture). This fragmentation inhibits collaborative work on systemic challenges like poverty and homelessness. By seeing the entire landscape of value creation and how these subsectors weave together across levels, organizations can coordinate more effectively on shared large-scale goals like community flourishing. A third reason is the balancing of power differentials. Scarcity of financial capital magnifies the power of funders (Choi 2017). Illuminating the entire spectrum of resources that stakeholders bring to the table can help balance those power differentials. A capabilities (multiple capitals) approach may also reduce reporting burdens by unifying strategy and accounting into an accountability framework that is usable in multiple contexts. Finally, a multiple capitals approach can illuminate fundamental aspects of the nonprofit sector's value creation currently overlooked by conventional accounting.

Adopting this capitals framework across multiple scales (individuals, organizations, networks, regions, states, and nationally) aligns stakeholders' different visions of what success looks like-capabilities development. This multiple capitals approach also provides a cohesive and compelling policy narrative. Figure 2 illustrates how a capabilities approach, using multiple capitals as measures, can scale across levels (individual, organizational, collaboration, community, nation), perhaps connecting to global initiatives such as the United Nations' Sustainable Development Goals (SDGs). 

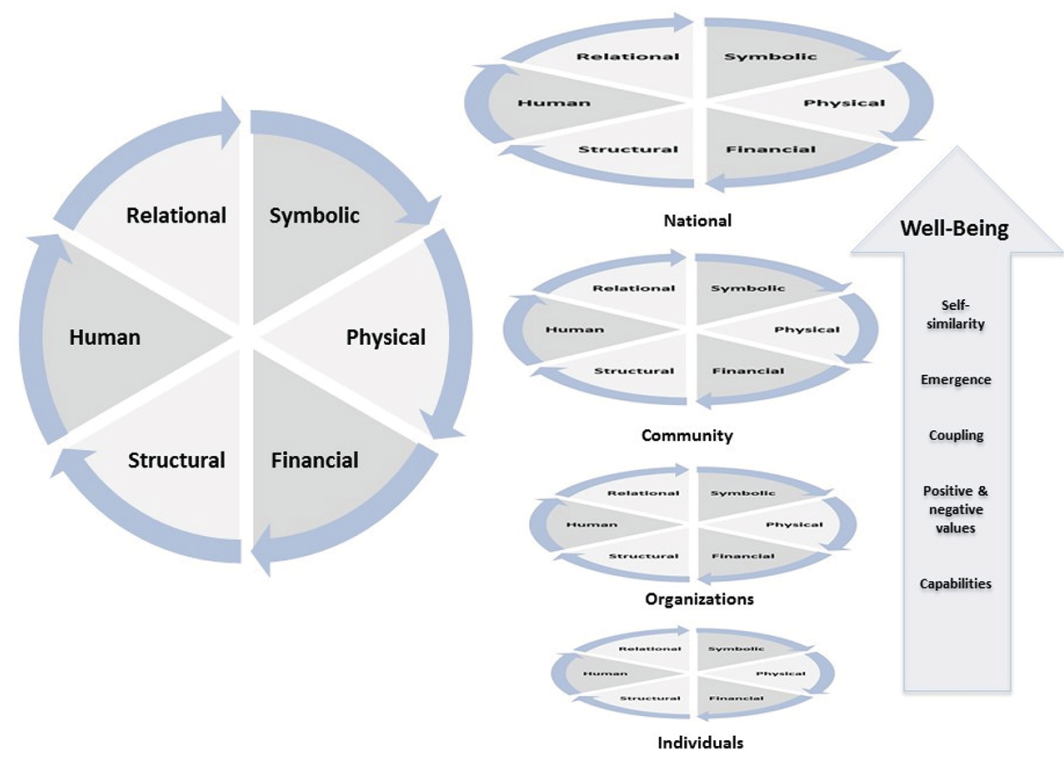

Figure 2: Fractal architecture. Integrated reporting and its multiple capitals framework can be used at any level (e. g., individual, organization, community, national). Investment in capabilities at lower levels expands degrees of freedom for both that level and above, producing emergent macro properties. For example, Mortenson (1997) empirically demonstrated how investment in higher education produces individual benefits for the learner as well as macro-level benefits such as a stronger tax base, prepared workforce, higher levels of parent involvement in schools, and higher levels of civic participation.

The flexibility of this capabilities architecture acknowledges and accommodates the importance of context. Best practices in Integrated Reporting require a section called Materiality to discuss potential risks (e. g. financial, environmental, social) to performance and goal attainment and how the organization plans to address and manage that risk (Eccles, Krzus, and Ribot 2015). In that section, nonprofit organizations would discuss their particular demographics, financial and governance regulations, community needs, and other contextually unique aspects of their operations to provide a complete picture of their operating environment. The best Integrated Reports use a blend of qualitative descriptions, quantitative measures, and data visualization to depict "... the relationship between a company's environmental, social, and governance performance and its profitability and value" (Eccles, Krzus, and Ribot 2015,115). While metrics are not yet standardized, Integrated Reporting offers a conceptual framework to align collective problem framing and solution creation.

\section{Accounting for Interaction Effects across Levels}

The previous sections described how capabilities can be operationalized as multiple forms of capital and measured at the individual, organizational, and societal levels. The case example illustrated in a simplistic way how value is created across multiple levels over time by converting resource inputs into outputs, outcomes, and impact. It also visualized how some of these externalities cycle back to become new inputs for various levels.

Figure 3 illustrates development as the dynamic flow of capabilities across multiple levels through interaction effects over time. This figure is inspired by Gottlieb's notion of probabilistic epigenesis, a model he developed over many decades of empirical work studying growth and development in birds. His research suggests that development is not a linear process, but rather the qualitative reorganization of structures arising from interactions across multiple levels, e. g. genes, neural activity, behavior, and higher levels of cognitive function (Valsiner 2007). Understanding the interplay between these various levels requires both qualitative and quantitative analysis (Valsiner 2007; Shrestha and Arnett 2008). 


\section{Bidirectional influences}

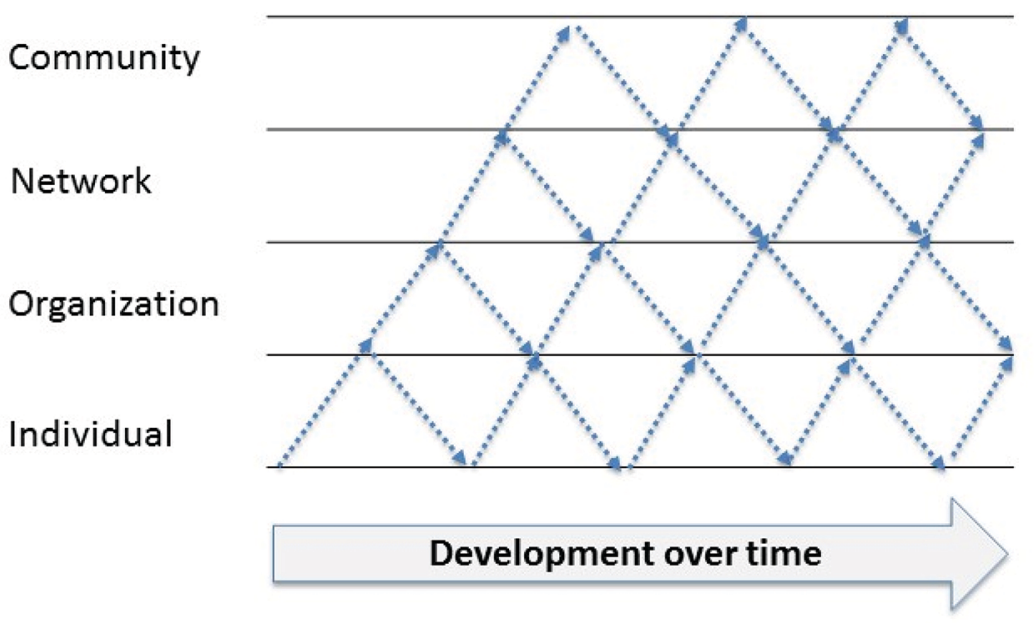

Figure 3: Development over time through multi-level interaction effects.

Ecology similarly examines interdependent processes and relationships across multiple levels, e. g. organisms, populations, communities, food webs, and ecosystems over multiple time scales (Woodward, Perkins, and Brown 2010). To deal with such complexity, ecologists first seek qualitative understanding, e. g. pattern recognition. The nonprofit sector must similarly learn to identify patterns across multiple levels, such as the development and transformation of capabilities across scales.

In the natural sciences, computational science methods like agent-based modeling (ABM) have become important tools to understand such complex behavior. ABM has shown great analytical capacity to reveal underlying dynamics of complex adaptive systems. ABM conducts experiments in silico, revealing patterns that develop through repeated interactions among individual agents over time. These patterns sometimes include self-organization and emergence, leading to insights about generative mechanisms underlying those phenomena (Macal and North 2010).

Because ABM has the computational capacity to handle vast amounts of data, it is increasingly embraced as a policy tool in fields such as epidemiology (Auchincloss and Diez Roux 2008), land use planning (Matthews et al. 2007), and economics (Farmer and Foley 2009). Empirical data ideally informs model development (Janssen and Ostrom 2006) through a participatory process that includes affected stakeholders (Vennix 1999). In the context of a nonprofit sector index, ABM can accommodate non-standardized data from the individual, organization, and community levels to populate computer simulations. Experimenting with different parameters (e. g. differences in operating contexts, policies, types and quantities of capabilities) can increase understanding of synergies, tradeoffs, and policy options.

\section{Policy Implications and Concluding Thoughts}

This paper has outlined a conceptual framework to guide development of a multi-level nonprofit sector index using a capabilities approach. It described multiple capitals as a way to operationalize and align capabilities across multiple levels. While these levels are not yet quantitatively comparable, this framework creates an architecture that can accommodate emergence and interaction effects across multiple levels and time scales. Thus, it avoids reductionism and loss of synergy through decoupling.

The final section of this paper presented two examples from the natural sciences to show how synergies, tradeoffs, and interaction effects across levels can be investigated and modeled. Computational science offers a promising path to generate new insights as to how capitals (capabilities) produce synergistic effects, what factors enable and constrain that production, and how various contexts impact production and recirculation. From a practical standpoint, rather than adopting simplistic measures (e. g. efficiency ratios, indirect cost rates) that can degrade long-term capacity, agent-based modeling can help philanthropists and policymakers create investments and policies that develop capabilities that lead to increasing returns (Busenitz and Barney 1997).

Admittedly this paradigm shift to social accounting will take time, just as it took time to evolve and standardize financial reporting. What might we learn from another historic paradigm transition? Six hundred years ago, people "knew" that matter existed in two forms, liquid and solid. As scientists began to suspect that a third form of matter existed (gases), they did not start by insisting on quantification. Rather, they carefully 
and repeatedly observed dynamic interactions and their effects. Over time, they began to recognize patterns, eventually enabling them to understand the underlying mechanisms and principles (e. g. how mass, volume, pressure, and temperature affect molecular interactions). By developing sufficient qualitative understanding through experimentation and analysis, the ability to measure ultimately followed (Gaston, Subramanian, and Zauscher 2006). As policymakers, philanthropists, nonprofit professionals, volunteers, and scholars develop a new understanding of intangible resources and complexity dynamics, the capacity to develop a quantified index will similarly emerge.

\section{References}

Ackoff, R. L. 1979. “The Future of Operational Research Is Past." Journal of Operations Research Society 30 (2): 93-104.

Allee, Verna. 2000. "Reconfiguring the Value Network." Journal of Business Strategy 21 (4): 36-39. https://doi.org/10.1108/eb040103.

Anand, Paul, Graham Hunter, lan Carter, Keith Dowding, Francesco Guala, and Martin Van Hees. 2009. “The Development of Capability Indicators." Journal of Human Development and Capabilities 10 (1): 125-52.

Auchincloss, Amy H., and Ana V. Diez Roux. 2008. “A New Tool for Epidemiology: The Usefulness of Dynamic-Agent Models in Understanding Place Effects on Health." American Journal of Epidemiology 168 (1): 1-8.

Bandura, Albert. 2006. “Toward a Psychology of Human Agency.” Perspectives on Psychological Science 1 (2): 164-80.

Baum, Joel A. C., and Jitendra V. Singh. 1994. “Organizaton-Environment Coevolution.” In Evolutionary Dynamics of Organizations, edited by Joel A.C. Baum and Jitendra V. Singh, 379-402. New York, NY: Oxford University Press.

Bourdieu, Pierre. 1989. “Social Space and Symbolic Power." Sociological Theory 7 (1): 14-25. https://doi.org/10.2307/202060.

Bourdieu, Pierre. 1993. The Field ofCultural Production: Essays on Art and Literature. New York, NY: Columbia University Press.

Bowles, Samuel. 1991. “What Markets Can—And Cannot—Do." Challenge 34 (4): 11-16.

Brown, Kerry A., Robyn L. Keast, Jennifer M. Waterhouse, Glen D. Murphy, and Myrna Mandell. 2012. “Co-Management to Solve Homelessness: Wicked Solutions to Wicked Problems." In New Public Covernance, the Third Sector, and Co-Production, edited by Victor Pestoff, Taco Brandsen and Bram Verschuere, 211-26. New York: Routledge. http://www.routledge.com/books/details/9780415897136/.

Bruni, Luigino. 2008. Reciprocity, Altruism, and the Civil Society: In Praise of Heterogeneity. London, UK: Routledge.

Burchell, S., C. Clubb, and A. C. Hopwood. 1985. "Accounting in Its Social Context: Towards a History of Value Added in the United Kingdom." Accounting, Organizations and Society 10 (4): 381-413.

Busenitz, Lowell W., and Jay B. Barney. 1997. “Differences between Entrepreneurs and Managers in Large Organizations: Biases and Heuristics in Strategic Decision-Making." Journal of Business Venturing 12 (1): 9-30. https://doi.org/10.1016/So883-9026(96)00003-1.

Cameron, James, and Juli Abouchar. 1991. "The Preautionary Principle: A Fundamental Principle of Law and Policy for the Protection of the Clobal Environment." Boston College International and Comparative Law Review 14 (1): 1-27.

Carlson, J. M., and John Doyle. 2002. “Complexity and Robustness." Proceedings of the National Academy of Sciences 99 (1): 2538-45.

Casey, K. L. 2008. “Defining Political Capital: A Reconsideration of Bourdieu's Interconvertibility Theory.” Lab for Integrated Learning and Technology. University of Missouri. http://citeseerx.ist.psu.edu/viewdoc/download?doi=10.1.1.502.5941\&rep=rep1\&type=pdf

Castillo, Elizabeth A. 2016. “Beyond the Balance Sheet." Journal of Nonprofit Education and Leadership 6 (3): 287-303.

Castillo, Elizabeth A., and Mai P. Trinh. Forthcoming. "Catalyzing Capacity: Absorptive, Adaptive, and Cenerative Leadership." Journal of Organizational Change Management.

Chen, Jin, Zhaohui Zhu, and Hong Yuan Xie. 2004. "Measuring Intellectual Capital: A New Model and Empirical Study." Journal of Intellectual Capital 5 (1): 195-212. https://doi.org/10.1108/14691930410513003.

Choi, Jennifer. 2017. "To Build Health Relationships with Grantees, Funders Need to Shift the Power Dynamics." National Council for Responsible Philanthropy. Web Log [October 20, 2017] retrieved from https://www.ncrp.org/2017/10/build-healthy-relationships-granteesfunders-need-shift-power-dynamics.html

Cohen, Wesley M., and Daniel A. Levinthal. 1990. “Absorptive Capacity: A New Perspective on Learning and Innovation." Administrative Science Quarterly 35 (1): 128-52. https://doi.org/10.2307/2393553.

Cravens, Karen, Elizabeth Coad Oliver, and Sridhar Ramamoorti. 2003. “The Reputation Index:: Measuring and Managing Corporate Reputation." European Management Journal 21 (2): 201-12. https://doi.org/10.1016/S0263-2373(03)00015-X.

Cutter, Susan L., Lindsey Barnes, Melissa Berry, Christopher Burton, Elijah Evans, Eric Tate, and Jennifer Webb. 2008. “A Place-Based Model for Understanding Community Resilience to Natural Disasters." Global Environmental Change, Local Evidence on Vulnerabilities and Adaptations to Clobal Environmental Change 18 (4): 598-606. https://doi.org/10.1016/j.gloenvcha.2008.07.013.

De Soto, Hernando 2000. The Mystery of Capital: Why Capitalism Triumphs in the West and Fails Everywhere Else, New York, NY: Basic Books.

Deitrick, Laura, Hans Schmitz, Marcus Lam, Crystal Trull, and Tessa Tinkler. 2016. Annual Report: State of Nonprofts and Philanthropy in San Diego. San Diego, CA: Caster Family Center for Nonproft and Philanthropic Research, University of San Diego.

Doolin, Bill. 1998. “Information Technology as Disciplinary Technology: Being Critical in Interpretive Research on Information Systems." Journal of Information Technology 13 (4): 301-11. https://doi.org/10.1057/jit.1998.8.

Ebrahim, Alnoor. 2010. "Nonprofit Agency Challenges." Journal of Policy Analysis and Management 29 (3): 628-32.

Eccles, Robert G., Michael P. Krzus, and Sydney Ribot. 2015. “Models of Best Practice in Integrated Reporting 2015." Journal of Applied Corporate Finance 27 (2): 103-15.

Emery, Mary, and Cornelia Flora. 2006. "Spiraling-Up: Mapping Community Transformation with Community Capitals Framework." Community Development 37 (1): 19-35. https://doi.org/10.1080/15575330609490152.

Fairholm, Matthew R., and Michael Card. 2009. "Perspectives of Strategic Thinking: From Controlling Chaos to Embracing It." Journal of Management \& Organization 15 (1): 17-30. https://doi.org/10.1017/S1833367200002856. 
Farmer, J. Doyne, and Duncan Foley. 2009. “The Economy Needs Agent-Based Modeling." Nature 460: 685-86.

Fletcher, Anne, James Guthrie, Peter Steane, Cöran Roos, and Stephen Pike. 2003. "Mapping Stakeholder Perceptions for a Third Sector Organization." Journal of Intellectual Capital 4 (4): 505-27. https://doi.org/10.1108/14691930310504536.

Folke, Carl. 2006. "Resilience: The Emergence of a Perspective for Social-Ecological Systems Analyses." Clobal Environmental Change 16: 25367.

Foucault, Michel 1984. The Foucault Reader, New York, NY: Pantheon Books.

Fowler, Alan. 2004. "Civil Society Capacity Building and the HIV/AIDS Pandemic: A Development Capital Perspective and Strategies for NCOs." presented at the PSO Capacity Building in Developing Countries, The Hague, NL, November 19.

Fukuyama, Francis. 2001. “Social Capital, Civil Society and Development.” Third World Quarterly 22 (1): 7-20. https://doi.org/10.1080/713701144.

Galbraith, Jay R. 1995. Designing Organizations: An Executive Briefing on Strategy, Structure, and Process. San Francisco, CA: Jossey-Bass.

Galbraith, Jay R 2011. Designing the Customer-Centric Organization: A Guide to Strategy, Structure, and Process, San Francisco, CA: John Wiley \& Sons.

Gaston, Cassandra, Aneesh Subramanian, and Melanie Zauscher. 2006. "The History behind the Discovery of the Earth's Atmospheric Composition." Reviews of Atmospheric Science Topics $12(\mathrm{X})$. http://citeseerx.ist.psu.edu/viewdoc/download?doi=10.1.1.598.741\&rep=rep1\&type=pdf.

Goodchild, Michael F., and Donald G. Janelle. 2010. "Toward Critical Spatial Thinking in the Social Sciences and Humanities." CeoJournal 75 (1): 3-13. https://doi.org/10.1007/s10708-010-9340-3.

Graeber, David. 2001. Toward an Anthropological Theory of Value: The False Coin of Our Own Dreams. New York, NY: Palgrave.

Gray, Rob. 2006. "Social, Environmental and Sustainability Reporting and Organisational Value Creation?: Whose Value? Whose Creation?" Accounting, Auditing \& Accountability Journal 19 (6): 793-819. https://doi.org/10.1108/09513570610709872.

Head, Brian W., and John Alford. 2015. “Wicked Problems: Implications for Public Policy and Management." Administration \& Society 47 (6): 711-39. https://doi.org/10.1177/0095399713481601.

International Integrated Reporting Council and The Chartered Institute of Public Finance and Accountancy. 2016 September. "Integrated thinking and reporting: Focusing on value creation in the public sector." London, UK: International Integrated Reporting Council. Accessed November 1, 2017. http://integratedreporting.org/wp-content/uploads/2016/o9/Focusing-on-value-creation-in-the-publicsector__vFINAL.pdf.

Janssen, Marco, and Elinor Ostrom. 2006. “Empirically Based, Agent-Based Models.” Ecology and Society 11 (2): 37 [online]. Jennings, Jay, and Emily Einsohn Bhandari. 2018. 2018 Texas Civic Health Index. Austin, TX: The University of Texas at Austin

Jones, J. A., Caitlin J. Hunter, Tracy Irani, Muthusami Kumaran, Angela B. Lindsey, and Dale Pracht. 2016. The Pulse of the Sector: Nonprofit Organizations in North Central Florida. Gainesville, FL: Institute of Food and Agricultural Sciences, University of Florida.

Kanter, Beth, and Katie Paine. 2012. Measuring the Networked Nonprofit: Using Data to Change the World. San Francisco, CA: Jossey-Bass.

Kato, Shoko, Shena R. Ashley, and Rasheda L. Weaver. 2017. “Insights for Measuring Social Value: Classification of Measures Related to the Capabilities Approach." Voluntas. Online first. https://doi.org/10.1007/s11266-017-9912-7.

Kee, Youngwha. 2017. “Multi-Dimensional Model of Community Well-Being from a Public Service Delivery Perspetive." In Handbook of Community Well-Being Research, edited by Rhonda Phillips and Cecilia Wong, 69-84. New York, NY: Springer.

Kenny, Charles. 2018. "Speeding Sustainable Development: Integrating Economic, Social, and Environmental Development." CCD Working Paper 484. Washington, DC: Center for Clobal Development. https://www.cgdev.org/publication/speeding-sustainable-developmentintegrating-economic-social-and-environmental

Kim, Yunji. 2016. "Community Wellbeing Indicators and the History of beyond GDP." Research and Policy Brief Series 73 (June 2016). Ithaca, NY: Cornell University. https://cardi.cals.cornell.edu/sites/cardi.cals.cornell.edu/files/shared/PolicyBrief]une-16_draft5.pdf

King, Daniel. 2017. “Becoming Business-Like: Governing the Nonprofit Professional." Nonprofit and Voluntary Sector Quarterly 46 (2): $241-60$. Kong, Eric, and Daniel Prior. 2008. "An Intellectual Capital Perspective of Competitive Advantage in Nonprofit Organisations." International Journal of Nonprofit and Voluntary Sector Marketing 13 (2): 119-28. https://doi.org/10.1002/nvsm.315.

Lakon, Cynthia M., Dionne C. Godette, and John R. Hipp. 2008. "Network-Based Approaches for Measuring Social Capital." In Social Capital and Health, edited by I. Kawachi, S. V. Subramanian and Daniel Kim, 63-81. New York, NY: Springer.

Land, K. C. 1996. "Social Indicators and the Quality of Life: Where Do We Stand in the Mid-1990s?" Sinet 45: 5-8.

Lecy, Jesse D., and Elizabeth A. M. Searing. 2015. "Anatomy of the Nonprofit Starvation Cycle: An Analysis of Falling Overhead Ratios in the Nonprofit Sector." Nonprofit and Voluntary Sector Quarterly 44 (3): 539-63. https://doi.org/10.1177/0899764014527175.

The Legatum Institute. 2017. The Legatum Prosperity Index 2017. London, UK: The Legatum Institute. http://prosperitysite.s3accelerate.amazonaws.com/3515/1187/1128/Legatum_Prosperity_Index_2017.pdf.

Lev, Baruch. 2005. “Intangible Assets: Concepts and Measurements." In Encyclopedia of Social Measurement, vol. 2, edited by K. KempfLeonard, 299-305. Amsterdam, NT: Elsevier, Inc.

Liebowitz, Jay, and Ching Y. Suen. 2000. “Developing Knowledge Management Metrics for Measuring Intellectual Capital." Journal of Intellectual Capital 1 (1): 54-67. https://doi.org/10.1108/14691930010324160.

Macal, C. M., and M. J. North. 2010. “Tutorial on Agent-Based Modeling and Simulation." Journal of Simulation 4 (3): 151-62.

March, James C. 1991. “Exploration and Exploitation in Organizational Learning." Organization Science 2 (1): 71-87.

Marcus, Lars. 2010. “Spatial Capital.” The Journal of Space Syntax 1 (1): 30-40.

Maruyama, Magoroh. 1978. "Heterogenistics and Morphogenetics: Toward a New Concept of the Scientific." Theory and Society 5 (1): 75-96.

Maslow, Abraham H. 1966. The Psychology of Science. New York, NY: Harper \& Row.

Matthews, Robin B., Nigel G. Gilbert, Alan Roach, J. Gary Polhill, and Nick M. Gotts. 2007. “Agent-Based Land-Use Models: A Review of Applications." Landscape Ecology 22 (10): 1447-59.

Mayer, Igor S., Els van Daalen, and Pieter W. C. Bots. 2013. “Perspectives on Policy Analysis: A Framework for Understanding and Design," in Public Policy Analysis: New Developments, edited by W. Thissen, and W. Walker, 41-64. New York, NY: Springer.

McCann, Kevin S. 2000. “The Diversity-Stability Debate.” Nature 405: 228-33. 
Meadows, D. 1998. Indicators and Information Systems for Sustainable Development. Hartland, VT: The Sustainability Institute.

Moncrieffe, Joy. 2011. Relational Accountability: Complexities of Structural Injustice. London, UK: Zed Books Ltd.

Mook, Laurie. 2014. "An Integrated Social Accounting Model for Nonprofit Organizations." In Accountability and Social Accounting for Social and Non-Profit Organizations (Advances in Public Interest Accounting, Vol. 17), edited by E. Costa, L.D. Parker and M. Andreaus, 197-221. Bingley, UK: Emerald Publishing Limited.

Mook, Laurie, and Rodney Machokoto. 2017. “Social Accounting.” In Clobal Encyclopedia of Public Administration, Public Policy, and Covernance, edited by A. Farazmand: Springer International. 10.1007/978-3-319-31816-5_2780-1. https://link.springer.com/referenceworkentry/10.1007\%2F978-3-319-31816-5_2780-1.

Mook, Laurie, Betty Jane Richmond, and Jack Quarter. 2003. “Integrated Social Accounting for Nonprofits: A Case from Canada." Voluntas: International Journal of Voluntary and Nonprofit Organizations 14 (3): 283-97. https://doi.org/10.1023/A:1025614619742.

Morris, Susannah. 2000. "Defining the Nonprofit Sector: Some Lessons from History." Voluntas: International Journal of Voluntary and Nonprofit Organizations 11 (1): 25-43. https://doi.org/10.1023/A:1008950915555.

Mortenson, Thomas C. 1997. “Private Correlates of Educational Attainment." Postsecondary Education Opportunity 61: 123-39.

Muller, Nicholas Z., Robert Mendelsohn, and William Nordhaus. 2011. "Environmental Accounting for Pollution in the United States Economy." American Economic Review 101 (5): 1649-75. https://doi.org/10.1257/aer.101.5.1649.

National Conference on Citizenship. 2017. Civic Health Initiative: Full Summary of Partnership Opportunity. Washington, DC: National Conference on Citizenship.

Nature. 2018. “Evolvability.” https://www.nature.com/subjects/evolvability

Nicholls, Alex. 2009. “'We Do Good Things, Don't We?' ‘Blended Value Accounting' in Social Entrepreneurship.” Accounting, Organizations, and Society 34 (6-7): 755-69.

Niven, Paul R 2011. Balanced Scorecard: Step-by-Step for Government and Nonprofit Agencies, Hoboken, N]: John Wiley \& Sons.

Norris, Tyler. 2014. "Healthy Communities at Twenty-Five: Participatory Democracy and the Prospect for American Renewal." National Civic Review 102 (4): 4-9.

Nussbaum, Martha C. 2001. Women and Human Development: The Capabilities Approach. Cambridge, UK: Cambridge University Press.

Nussbaum, Martha C. 2011. Creating Capabilities. Cambridge, MA: Harvard University Press.

Petty, Richard, and James Cuthrie. 2000. "Intellectual Capital Literature Review: Measurement, Reporting and Management." Journal of Intellectual Capital 1 (2): 155-76. https://doi.org/10.1108/14691930010348731.

Rickles, Dean, Penlope Hawe, and Alan Shiell. 2007. "A Simple Guide to Chaos and Complexity." Journal of Epidemiology \& Community Health 61 (11): 933-37.10.1136/jech.2006.054254.

Rittel, Horst W. J., and Melvin M. Webber. 1973. “Dilemmas in a General Theory of Planning.” Policy Sciences 4 (2): 155-69. https://doi.org/10.1007/BF01405730.

Rutten, Roel, Hans Westlund, and Frans Boekema. 2010. "The Spatial Dimension of Social Capital." European Planning Studies 18 (6): $863-71$. https://doi.org/10.1080/09654311003701381.

Santos, Alvaro. 2012. “The World Bank's Uses of the ‘Rule of Law' Promise in Economic Development." SSRN Scholarly Paper ID 2034333. Rochester, NY: Social Science Research Network. https://papers.ssrn.com/abstract=2034333.

Schmidt, Tobias. 2010. "Absorptive Capacity-One Size Fits All? A Firm-Level Analysis of Absorptive Capacity for Different Kinds of Knowledge." Managerial and Decision Economics 31 (1): 1-18. https://doi.org/10.1002/mde.1423.

Scott, Carol. 2011 September. "Measuring the Immeasurable: Capturing Intangible Values." In Conference keynote presented at Marketing and Public Relations International Committee of ICOM. Accessed. http://network.icom.museum/fileadmin/user_upload/minisites/mpr/papers/2011-Scott.pdf.

Seattle City Club. 2018. 2017 Greater Seattle Civic Health Index. Seattle, WA: Seattle City Club. Accessed. http://civic-healthindex.seattlecityclub.org/2018-update.

Seitanidi, Maria May. 2007. "Intangible Economy: How Can Investors Deliver Change in Businesses?: Lessons from Nonprofit-Business Partnerships." Management Decision 45 (5): 853-65. https://doi.org/10.1108/00251740710753675.

Sen, Amartya. 2005. “Human Rights and Capabilities.” Journal of Human Development 6 (2): 151-66. https://doi.org/10.1080/14649880500120491.

Shrestha, Sadeep, and Donna K. Arnett. 2008. "Research Methods for Cenetic Studies." In Essentials of Clinical Research, edited by S. P. Classer, 181-99. New York, NY: Springer.

Skaaning, Svend-Erik. 2010. “Measuring the Rule of Law." Political Research Quarterly 63 (2): 449-60. https://doi.org/10.1177/1065912909346745.

Sorter, Ceorge H. 1969. “An ‘Events' Approach to Basic Accounting Theory.” The Accounting Review 44 (1): 12-19.

Stevens Institute of Technology. 2006. Report on System of Systems Engineering. Hoboken, N]: Stevens Institute of Technology. http://www.boardmansauser.com/downloads/SoSSEreporttoDoD.pdf.

Stock, James H., and Mark W. Watson. 1989. "New Indexes of Coincident and Leading Economic Indicators." NBER Macroeconomics Annual 4: 351-94.

Sustainability Accounting Standards Board. 2018. https://www.sasb.org

Tidball, Keith G., and Elon D. Weinstein. 2011. "Applying the environment shaping methodology: Conceptual and practical challenges." Journal of Intervention and Statebuilding 5, no. 4:369-394.

Todorova, G., and B. Durisin. 2007. "Absorptive Capacity on Business Unit Innovation and Performance." Academy of Management Journal 44 (5): 996-1004.

Toro, Paul A., and Melissa G. Warren. 1999. “Homelessness in the United States: Policy Considerations." Journal of Community Psychology 27 (2): 119-36.

Valsiner, Jaan. 2007. “Gilbert Cottlieb's Theory of Probabilistic Epigenesis: Probabilities and Realities in Development." Developmental Psychobiology 49 (8): 832-40. 
Van Der Gaag, Martin, and Martin Webber. 2008. “Measurement of Individual Social Capital." In Social Capital and Health, edited by I. Kawachi, S. V. Subramanian and Daniel Kim, 29-50. New York, NY: Springer.

Vennix, Jac A. M. 1999. “Croup Model-Building: Tackling Messy Problems.” System Dynamics Review 15 (4): $379-401$.

Vosselman, Ed. 2016. "Accounting, Accountability, and Ethics in Public Sector Organizations: Toward a Duality between Instrumental Accountability and Relational Response-Ability." Administration \& Society 48 (5): 602-27. https://doi.org/10.1177/0095399713514844.

Warner, Karen, and Margaret Kern. 2013. A City of Wellbeing: The What, Why, and How of Measuring Community Wellbeing. Santa Monica, CA: City of Santa Monica Office of Wellbeing. http://communityindicators.net/wpcontent/uploads/2017/12/MeasuringCommunityWellbeing_Whitepaper2013.pdf.

Wartick, Steven L. 2002. “Measuring Corporate Reputation: Definition and Data.” Business \& Society 41 (4): 371-92. https://doi.org/10.1177/0007650302238774.

Weber, Edward P., and Anne M. Khademian. 2008. "Wicked Problems, Knowledge Challenges, and Collaborative Capacity Builders in Network Settings." Public Administration Review 68 (2): 334-49. https://doi.org/10.1111/j.1540-6210.2007.00866.x.

Wing, K., and M. A. Hager. 2004. “Cetting What We Pay For: Low Overhead Limits Nonprofit Effectiveness (Brief No. 3).” Brief No. 3. Washington, D.C.: The Urban Institute.

Woodward, Guy, Daniel M. Perkins, and Lee E. Brown. 2010. “Climate Change and Freshwater Ecosystems: Impacts across Multiple Levels of Organization." Philosophical Transactions of the Royal Society 365: 2093-106.

Zietlow, John. 2010. "Nonprofit Financial Objectives and Financial Responses to a Tough Economy." Journal of Corporate Treasury Management $3(3): 238-48$. 